This item was submitted to Loughborough's Research Repository by the author.

Items in Figshare are protected by copyright, with all rights reserved, unless otherwise indicated.

\title{
Post-conflict statebuilding and state legitimacy: from negative to positive peace?
}

PLEASE CITE THE PUBLISHED VERSION

http://dx.doi.org/10.1111/j.1467-7660.2008.00495.x

PUBLISHER

Blackwell Publishing (@ Institute of Social Studies)

VERSION

AM (Accepted Manuscript)

LICENCE

CC BY-NC-ND 4.0

REPOSITORY RECORD

Roberts, David. 2019. "Post-conflict Statebuilding and State Legitimacy: From Negative to Positive Peace?". figshare. https://hdl.handle.net/2134/15361. 
This item was submitted to Loughborough's Institutional Repository (https://dspace.lboro.ac.uk/) by the author and is made available under the following Creative Commons Licence conditions.

\section{creative
commons}

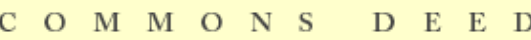

Attribution-NonCommercial-NoDerivs 2.5

You are free:

- to copy, distribute, display, and perform the work

Under the following conditions:

Attribution. You must attribute the work in the manner specified b the author or licensor.

Noncommercial. You may not use this work for commercial purposes.

No Derivative Works. You may not alter, transform, or build upon this work.

- For any reuse or distribution, you must make clear to others the license terms of this work.

- Any of these conditions can be waived if you get permission from the copyright holder.

Your fair use and other rights are in no way affected by the above.

This is a human-readable summary of the Leqal Code (the full license).

\section{Disclaimer 만}

For the full text of this licence, please go to: http://creativecommons.org/licenses/by-nc-nd/2.5/ 


\title{
Statebuilding 3.0: Building Local Legitimacy, Essential Security and Global Governance
}

\begin{abstract}
:
This work is concerned with the local legitimacy of formal postconflict statebuilding. Much recent scholarship has stressed the legitimacy of a state's behaviour in relation to conformity to global governance norms, while others are concerned with a reformed state's legitimacy regarding democratic 'best practice'. Less evident is a discussion of the extent to which newly-enshrined or redeveloped postconflict polities are able to engender the societal legitimacy central to political stability. As long as this level of legitimacy is absent (and it is hard to generate), civil society will likely remain distant from the state, and peace and stability may remain elusive. A solution to this may be to apply existing international legislation centred in the UN and the International Labour Organization to compel international organizations and national states to deliver through their institutions basic needs security. This has the effect of instigating local-level state legitimacy while simultaneously sustaining global governance human rights regimes.
\end{abstract}

Keywords: Statebuilding; local legitimacy; essential human welfare; global governance

\section{Introduction}

Although they were not known as such, early statebuilding operations after 1989 were often ad hoc elaborations of more familiar Cold War UN Chapter Six peacekeeping operations, like West Irian and the Congo. The progressive nature of this elaboration reflected changes in UN permanent-five veto politics, and the concomitant rise in demand for conflict settlement and development. Various terms were proposed for these changes, from peacekeeping, through multi-dimensional and second generation operations (Lewis 1993; Mackinlay and Chopra 1993). The level of emphasis, however, was clear: 
operations were focused on achieving results in consensual host environments, and superpower, interests were more locally ascertained. ${ }^{1}$

Since then, the pendulum has again swung. Statebuilding 2.0, as I refer to it here, is a version of local intervention shaped and driven by external conditions. Where once superpower antagonisms framed international conflict resolution, more recently global governance has shaped emergent peace settlements and post-settlement development. This version of statebuilding, vastly up-scaled, more expensive, more intrusive and more complex, has come to represent the practice in which domestic democratization is externally-assisted to ensure conformity to international governance norms such as Liberal democracy and neoliberal economic practices whilst implanting rules and conditions for 'best practice' in national government. It creates terms to regulate internal state behaviour to secure peace such that a state’s credentials conform to international criteria for local democratic practices, whilst creating sovereign compliance with wider global governance demands. Statebuilding 2.0 and its role in wider peacebuilding facilitates states' connection to global governance regimes by harmonizing the rules of state behaviour with peace- and wealth-developing external bodies like the UN and World Bank and the global governance regimes for which they stand. Ottaway refers to such states as existing 'by a fiat of the international community which recognizes them as sovereign entities whether or not they have a government capable of effectively controlling or administering [a] territory’ (2002: 1003).

However, whilst this captures the urgency of the global 'democratization' debate, the emphasis on the local legitimacy of indigenous political institutions to the captive audience is much less studied, Despite the fairly limited (by comparison) consideration of this end of political legitimacy, the creation of a stable polity depends first and foremost

\footnotetext{
${ }^{1}$ Cambodia is slightly different. Ending the superpower patronage of the regional clients indicates that much was involved outside of Cambodia. This is because the Cold War was both played out and terminated before and after 1989, as a consequence of achieving a grass roots settlement that suited external actors more than it did several regional actors, including Viet Nam and Laos. International influence was sustained throughout the operation because both the US and China were tied to the Khmer Rouge, whose involvement had been a condition of US and Chinese consent to the operation. Operations after Cambodia were more distinctly rooted in the post-1989 era.
} 
on stability 'taking off' within the state being built or rebuilt, and this depends to a large extent on whether the elite is considered legitimate by its citizens. Without this relationship, there is less likely to be external validation of and cooperation with national polities, and even less of state conformity with international global governance regimes. I propose a revised approach to statebuilding to develop local legitimacy and its international corollary, which I refer to here as statebuilding 3.0.

This article reviews the split in the statebuilding literature between that emphasizing the enhancement of global governance norms and regimes; and that which addresses the impact of democracy in the statebuilding spaces to which it migrates. These spaces include post-conflict states, most normally those emerging from conflict shrouded by Cold War priorities. But they also include post-colonial states where there has been no conventional conflict, where the State is deemed to have failed and where intervention is consensual. The paper then discusses debates on achieving state-level democracy, between transitologists and structuralists, before surveying a further sub-element of the debate regarding 'democratic legitimacy' and 'performance legitimacy' at grass roots. The former refers to that type of democratization that finds acceptance with external observers, for example, in the evident holding of elections. The latter concerns whether the newly-acquired legitimacy conferred on the state from without is matched internally by societal consent to their State’s authority. Given deep and lengthy traditions of mistrust of the state per se in most statebuilding environs, it is suggested here that much more work is required to ensure any temporary local political stability is maintained in the immediate to short-term and beyond. This issue is at once essential as a foundational element of peace, statebuilding and peacebuilding, but is often low on the intervention's

agenda. I will then advance a potential solution which may create and/or underscore local legitimacy; enhance basic human rights; improve human security; and underscore global governance regimes.

\section{Statebuilding}

Statebuilding can be considered an evolution of early post-Cold War peacekeeping initiatives. Mandates were initially relatively limited in most cases. Key priorities 
involved, for example, electioneering in Namibia, and elections and demobilization in Angola, El Salvador and Mozambique. In Cambodia, an early manifestation of contemporary statebuilding became clearer. The UN operation there involved polling, disarmament, demobilization, demining and limited political trusteeship with suspended sovereignty. More recently, statebuilding operations' ambits have expanded to consider the ramifications not only of armed combatants and elite dysfunctionalism, but also of 'disintegrated capacity to respond to citizens' needs and desires, and [failure to] provide basic public services [and] assure citizens' welfare'. In addition, statebuilding addresses the absence, 'at the international level, of a credible entity that represents the state beyond its borders' (Brinkerhoff 2005: 3; Chandler 2007). Thus, statebuilding interventions may be considered in part as vehicles with a multilevel ambit, involving the creation and sustenance of global liberal norms through stabilizing local peace and development processes using liberal instruments and policies.

In order to achieve this, early post-Cold War engagements evinced an approach that came to be known as 'transitology'. Transitology relies on an assumption that, regardless of history, democracy is an essentially portable political system (Grugel 2002; Ignatieff 2003; Rustow 1970). Hopeful as this commitment to democracy export was, the 'transition paradigm' received short shrift as a result of a series of unreliable and inconsistent transformations in practice. It was further undermined by the belief that democratization can in some way reach an end point after a transitional process. It might instead be viewed as a journey, rather than a destination (Kingsbury 2007: 121; Carothers 2002). Reflecting these views, Cambodian political researchers concluded that Cambodia in 2006 was in a state of 'permanent transition'. ${ }^{2}$ This is but a reflection of all democratization as a social construction subject to permanent flux.

Transitology has not stood well the test of time or practice. Diamond et al (1999: ix) describe the outcomes of early transitions as 'pseudo-democracies', whilst Zakaria refers to them 'illiberal democracies' (1997: 27). Indeed, there has been much debate on exactly

\footnotetext{
${ }^{2}$ Kimchoeun Pak, Research Associate; Netra Eng, Research Associate; and Sedara Kim, interviews at Cambodia Development Resource Institute, Phnom Penh, $12^{\text {th }}$ July 2006.
} 
what to call such semi-transformed political spaces, with few considering that part of the definitional problem lies in its permanent attachment to democracy. Such vernacular fails to challenge the ethnocentrism of earlier imperial debacles. Furthermore, Rothstein suggests that such labeling may 'obscure more than it reveals in the non-Western world' (1992: 17). In an attempt to escape the limits of such vernacular, I propose a neologism, and refer here to such developments as 'hybrid polities'. These are polities that have experienced and reacted to external democratization forces, the outcome of which is the acceptance of certain elements of democracy such as pluralism, and the rejection of other aspects, such as the separation of powers.

The inverse of transitology may be found in the 'structuralist' school of political evolution. In this view, the preconditions for democracy have taken eons to evolve in Europe and cannot be simply compressed and telescoped into an abbreviated time period. This is in part because, in the period of human evolution that has furnished territorially bounded populations with elite leadership, different regions, religions, histories and sociologies, not to mention particular individuals and events, have produced quite different forms of 'governance', loosely defined. Many structuralists take the view that domestic political institutions evolve in response to effects experienced nationally (from within, without or both) over a normally lengthy period of time, absent revolutions which, in effect, are rarely revolutionary but products of more gradually-arising systemic pressures (Bratton and van de Walle 1997, 21-33; Grugel 2002: 51-6; LumumbaKasongo 2005: 2). As a result, so the argument goes, we should not safely anticipate that holding elections will result in durable democracy of any gravitas.

Chandler is also concerned that contemporary Liberalizing efforts involving political restructuring will not automatically facilitate or legitimate the state and its administrative institutions in the eyes of the governed (2007: 70-1). He draws our attention to the dissonance between external and internal processes, whereby the former is privileged and prioritized above the latter by external actors who see 'democracy and political autonomy [as] the end goal, rather than crucial aspects of the process of state-building itself' (2007: 71). For him, this is 'potentially the most worrying aspect of current state-building policy 
practices - the downplaying of the centrality of the political process' (2007: 71).

Chandler's work is set in a wider debate regarding epistemology and ontology; but in terms of statebuilding, its importance here is that it highlights the relegation of internal legitimacy-promoting processes at the expense of processes aimed at forming a state capable of fitting into and reflecting international norms.

Brinkerhoff concurs. In his view, a state's ability to 'respond to citizens needs and demands seems to take a lower priority’ compared with its ability to conform to international norms (2005: 5). It cannot be concluded that legitimacy as it is understood in Western State practices will evolve in very different societies at a different point in their own political development. It is very unlikely, in fact, that this would occur naturally or artificially in the short spaces of time associated with statebuilding. Part of the cause of this is a local legitimacy deficit. The following section discusses where this mistrust comes from, and how suspicion towards the State remains deeply embedded in many of the political spaces into which statebuilding initiatives venture. This is important in generating a reliable framework for understanding conditions in which State legitimacy is unlikely to develop, such that they may be addressed.

\section{Domestic legitimacy from past to present}

It would be unwise to suggest that every statebuilding environment is the same. However, in many instances, the theme of civil mistrust and elite manipulation of state institutions is common. Kamrava argues that 'in essence, the politics of the Third World is driven by continuous struggles on the part of governments to attain legitimacy and in the process to institutionalize themselves in their respective societies’ (1993: 2). But institutionalization cannot be considered without reference to the goals involved and how this confers or denies social acceptance and local legitimacy. This is an essential starting point in rethinking how we view state institutions from within: what do they mean, and for whom? The following are necessarily generalizations at a thematic level, and they reflect Englebert's argument that locates state illegitimacy 'at the core of the developmental failure of many African states’ (2002: 173). Furthermore, it reflects Bastian and Luckham’s argument that to understand such social relations requires 'a historical 
perspective... both to offset democracy Triumphalism and to counter pessimism over conflict and state failure' (2003: 306).

\section{Pre-imperial}

Before the northern European empires arrived in the Global South, whether indigenous state institutions existed or not, rural societies in many geographical spaces provided their own basic needs and often viewed elite institutions (where they existed and were recognized) in wealthy urban centres with suspicion (Phan Huy Le 1993; SarDesai 1992; Tambiah 1977). Travel was limited, population density was lower than currently, and local needs were furnished mainly locally. The state provided little, if any, of such basic needs, whilst merchants provided, where surplus permitted, additional goods beyond basic inputs. The centres of power gathered wealth through trade and war, and rarely took the view that they had a sovereign 'responsibility to protect' (Amin 1977; Tambiah 1977; Thomson 2000). These experiences are quite common: Burnell and Randall state that 'with few exceptions... few modern states [in the developing world] can trace their lineages back through indigenous systems and institutions of rule’ (2005: 145). The origins of political space and distance between civil society and elite centres are fairly consistent, and linked to many other wider social and economic forces (Clapham 2002).

\section{Imperial}

Although some have maintained that the imperial era involved an export of ideas, the notion of self-determination was not one of them. For many, but not all, newly-colonized and -bounded societies, the appearance of the metropolitan, far-reaching state in their midst, and the rules of conduct that accompanied it, were not vastly different from earlier experiences (Eisenstadt and Roniger 1982; Meredith 2005; Tambiah 1977). The relationship between civil society and imperial and locally co-opted elites was often violently extractive, and most of the key state institutions that civil society engaged with were of an authoritarian nature in the image of imperial domination. Colonial-imperial authority was resented, and not to be challenged without the threat of punishment through transparently abusive institutions. Quite brutal rule was normal, and often the State took the form of a hostile political body, to be feared by the population it sought to control. 
Again, such state institutions rarely provided for basic needs, and in some circumstances, essential needs were denied or stolen by elites and contributed to local perceptions of state illegitimacy (Jackson 2005; Rodney 1973; Tambiah 1977). In these malignant relations are the makings of fluid and constructed perceptions of state and institution illegitimacy. No concept of a social contract, or of a neutral bureaucracy, or of impartial and legal rule, existed to legitimate elites in the eyes of local populations. The structures and institutions set in place, although varying in grace, were generally of a hierarchical, authoritarian form (Davidson 1994; Feit 1973; Gutteridge 1969; Randall and Theobald 1985). Burnell and Randall describe the nature of colonial and post-colonial states as 'representing varying kinds of socio-economic elites and interests [lacking] the interest, the will, or the power' to promote broad social development or rights (2005: 145; see also Parry 1971). Elite interests were usually inimical with civil social concerns and often the former violently undermined the latter.

\section{Post-imperial}

Despite the physical departure of many European elites, the tradition of elite authoritarianism combined with questionable post-imperial authority to sustain statesocietal relationships of extraction and mistrust. The broad imperial traditions of personal authority and aggression from elites became more emphatically institutionalized and embedded in a locally-owned and informally-orientated state bureaucracy. Based on patronage and clientelism, elite extraction of resources from civil society to maintain non-consensual dominance persisted (Bunce 2000; Englebert 2002; Kilson 1963). Chazan et al note the end of imperial governance and its replacement with African leaders who 'were confronted with the paradoxical situation of having to operate with newly conceived pluralist institutions of alien derivation... [when their own backgrounds] had been molded in a centralized and authoritarian context' (1999: 45). Civil resentment, nourished by imperial violence in the decades before independence, was bolstered by the arrogance of elites, many of whom maintained imperial methods and characteristics whilst impeding progressive social reform (Kilson 1963: 284). Capital cities became icons of corruption and questionable modernity, in contrast with rural traditions deeply 
underpinned by, and dependent on, seasonal agricultural production and the small-time, but legitimately interpreted, relations of kinship and clientelism with relatively smallscale landowners. Vickery illustrates the resentment well, when he describes the arrival of visiting dignitaries in a small, rural location far from Phnom Penh, Cambodia, in the 1960s. 'An interesting feature of the village', he remarks, 'was the people’s dislike of anyone and anything from the towns'. He continues that, on one occasion, 'Officials... had come to visit... The villagers hated their pretensions and false promises of aid and development. Most of all they disliked the officials’ wives, who minced about... in high heels with handkerchiefs held to their nose...' (1984: 2). They were the extension of the rich and corrupt metropolis, to which few from the far rural areas related (Clapham 2002).

As post-colonial independence merged with the Cold War of the 1980 and 1990s, various indigenous leaders’ efforts to control diverse ethno-regional groupings, and ongoing internal challenges to elite legitimacy, merged with major Northern states' efforts to develop proxies in their global, ideological confrontation. Conditions were aggravated by external financial support from Western and Eastern banks and governments for ever more brutal regimes, further polarizing the civil society-state dichotomy. Von Einsedel remarks that this situation ensured that many indigenous elites 'had no interest in nurturing taxable autonomous groups of internal producers'. Instead, 'the situation allowed them... to impose heavy demands for resources on their own populations' (2005: 18).

In this process, great wealth was accumulated by the 'Big Men' like Mobutu, 'Emperor' Bokassa and Felix Houphouet-Boigny (to name but three) whilst great impoverishment diminished wider development. Elites prospered amongst bloody internecine violence whilst millions perished from avoidable diseases. In a sense, where the notion of the state many centuries ago may have provoked titillation or confusion amongst self-sustaining communities, it later provoked bitterness, resentment and mistrust. In short, such societies viewed and often continue to view state institutions with mistrust and foreboding, whilst elites often deploy state institutions less for public service and more 
for personal gain and the sustenance of authority through elite patronage and clientelism (Eisenstadt and Roniger 1982; Englebert 2002; Schmidt et al 1977).

State weakness in Africa particularly, but also in other regions, 'is a product of... history', and the mapping of external political values, institutions and processes 'over preexisting political structures'. These in turn were later adopted in many cases by Western-socialized elites who maintained the authoritarian domination they saw in their recent imperial past (2002: 74). The position of state institutions historically in the affairs of broader civil society has ensured that people have created or maintained their own informal social institutions to manage vital provision. Where no long-standing, formal relationship of state and society exists, the pattern has been that civil society fends for itself through informal practices of common social patronage; and, where they exist, elites carve up the benefits of state institutions to maintain their own networks of powerpreserving patronage and clientelism (Roberts 2008a). This is common throughout the developing world, although its 'distasteful' nature will often be denied by those practicing it (Bayart 1993; Bunce 2000; Eisenstadt and Roniger 1982; Kawata 2007; Levi-Strauss 1969; Schmidt et al 1977; Wolf 1966). Such relationships are so common that they are often arise in common vernacular, and as slang, demonstrating their pervasiveness. In Nigeria, the elite may be referred to as 'Wa-benzi', or the 'Mercedes Benz people/tribe', and in Cambodia, mass common social patronage is referred to by the term 'khsae', or 'string', denoting the wide and deep connective network of essential sustenance.

\section{A legitimacy deficit?}

A central theme, then, linking pre-colonial, imperial and independence eras may be broadly characterized as a combination of increasing contact with, and exploitation of, civil society by violent and penetrative state institutions, on the one hand, and a deepening of mistrust, disrespect and rejection of the legitimacy of state institutions and elites by civil society, on the other. Such conditions are important when considering the present position of state institutions and civil society since they are consciously inherited experiences and 'traditions' with socialized responses and reactions (Brahimi 2007; 
Englebert 2002). In a very real sense, the spaces that exist between civil society and elites have developed or been reinforced in accordance with experiences of state illegitimacy, and part of the problem in current statebuilding approaches lies in finding an approach that can close the gap between these two distant bodies, rather than inserting modern institutions that create external legitimacy but which crucially have little legitimacy for civil society, and which will be manipulated by elites to preserve their own power. Whilst this gap remains open, an opportunity to connect the two extremes, of state and society, is wasted.

\section{Forging legitimacy}

In many statebuilding interventions, the idea of legitimacy has been taken as read; but read by foreigners, often with very limited experience of how societies relate to the state, and sometimes without ever having lived in such an environment. In contrast, Milliken and Krause ask: 'what are the minimal conditions of governance required [for stable development]; and what are the roles and influence of the international community in creating these conditions?' (2002: 761). They are concerned less with satisfying an external audit, and more with creating conditions by which societies will not reject the legitimacy and authority of their leaders and so undermine the stability essential for peace and development.

Milliken and Krause identify a 'welfare and entitlement state as a powerful glue that binds citizens to their state' in an 'extension of the basis of state legitimacy...' They also remark, however, that 'the welfare functions of lesser-developed states are less likely to be able to provide for the basic needs of their populations' (2002: 760-2; emphasis in original). In other words, essential state welfare provision would most likely be conducive to establishing trust and legitimacy between governed and governors; but unsurprisingly, the states most likely to consent to statebuilders are probably least likely to have the resources to finance subsidies and basic welfare. Additionally, most states in such conditions have citizenry with mostly negative experiences of the idea of the state (see below), requiring perhaps a surfeit of trust to compensate (Brahimi 2007: 5). I will address this deficit later. 
In thinking about legitimacy, Francois and Sud (2006) also identify similar distinctions between its internal and external variants. Once particular Liberal processes have been commenced and engaged with, they validate democracy; the authors describe this as ‘democratic legitimacy’. However, Francois and Sud suggest that a second type of legitimacy can be 'derived from government performance and effectiveness in fulfilling core state functions'. The authors classify this as 'performance legitimacy' and add that 'states which fulfill the two core functions of security/territorial integrity and improvements in living standards possess performance legitimacy in the eyes of their citizens' (2006: 147). They add that 'states which do a good job fulfilling the two core state functions of security/territorial sovereignty and improvements in living standards possess performance legitimacy in the eyes of their citizens’ (2006: 147). Conversely, they add that 'the major determinant of state failure is the inability (or unwillingness) of states to improve the standard of living of their citizens' (Francois and Sud 2006: 142; this refers to state failure after statebuilding has started). Cichon and Hagemejer claim that State intervention in welfare would produce the 'societal cohesion that is needed for long term economic development' and which is central to the creation of state-societal stability (2007: 169). So convinced is Brinkerhoff of the importance of local state legitimacy that he calls for 'further work to elaborate frameworks that can incorporate the particulars of individual countries in addressing legitimacy...' (2005: 3).

The relationship between social provision and local stability via institutional legitimacy persists is also considered by Clapham. He argues that 'mayhem can be reduced, if not in every case prevented, by well-crafted intervention designed not only to strengthen states, but to meet the human needs that must ultimately justify their existence' (2003: 92). Similarly, Call and Cousens maintain that state legitimacy can be generated through a variety of approaches, included the more conventional method of securing border. But in addition, they also argue that 'the capacity to deliver core services to a vulnerable population' is another mechanism by which legitimacy may be secured (2008: 9). 
We may make a number of reasonable claims at this point. First, there are grounds to consider a relationship between political stability and the establishment of legitimacy on the part of the elite and state institutions. Second, absent these conditions, it is likely that local instability will render impossible or extremely difficult, other priorities of statebuilding, such as institutional capacity building; demobilization, disarmament and reintegration of armed forces; infrastructure repair; and so on. Third, there is a long history of resistance to the state, its institutions and the actors therein. Fourth, international institutions have to date had only limited success in improving local legitimacy. Milliken and Krause note that whilst it may be 'relatively easy to create institutional structures' without them being mere husks, 'the transformation of these structures into legitimate institutions is extremely difficult, and only marginally affected by external actors' (2002: 770).

\section{Developing state legitimacy through public goods provision}

In most statebuilding environments, three things persist: extreme peripheral poverty; mistrust of the state (especially where the state is perceived as the cause of such impoverishment); and weak state institutions. The essential question here is how to develop state legitimacy through essential welfare provision that is almost certainly beyond the capacity of the State to provide, since it will almost always be impoverished and incapable of raising sufficient tax revenue. I will elaborate below an approach to enhancing state legitimacy through international public lending targeted through local State institutions for essential welfare provision in the field of sanitation and hygiene. The UN has declared that 'diseases transmitted through water or human waste are the second leading cause of death among children worldwide... [amounting to] an estimated 3,900... every day' (UNDP 2005: 24). It is estimated by reliable sources that more than a billion people have no access to clean water at all, and nearly two-and-a-half billion lacked in basic sanitation (WHO 2005). The burden of disease aggravated by these conditions is crippling in future developmental terms, but also causes mass avoidable lethalities and expensive-to-treat sicknesses, like cholera, typhoid, sleeping sickness, malaria, yellow fever and guinea worm, to name but a few cited by the WHO (2005). Furthermore, the sicker children are, the less time they can spend in school, further 
undermining development and doing nothing at all for cementing positive relationships between State and society. Since this priority is recognized for its essential and foundational role in successful European development and prosperity in the early part of the $20^{\text {th }}$ Century, there should be no reason not to elevate and fund it, assuming development and prosperity are the objectives (WHO 2007: 2-4). This approach, if broadly applied, would likely prevent innumerable avoidable deaths in the most vulnerable 'under-fives’ category, create social trust in the State, underscore long-term development and reduce excessive birth rates and associated pressure on local resources. The process itself could be validated through independent accountability institutions, with further financial incentives for States achieving agreed targets (see below). Both international and local roles could be further validated against extant international legislation, with the effect of expanding domestic State legitimacy into the realm of international governance regimes (Ku and Diehl, 2006).

The concept of lending conditionality has been with us for some time. It has been applied with varying levels of success to countries in the developing world to economicallyincentivize democratic practices. It acts as a lever on internal political evolution, and is criticized by some as being neo-imperial in intention. It could, however, be applied much less contentiously to less ideologically-inflammatory subjects such as healthcare. Since it is clear in development and medical circles that basic and easily manageable illnesses like diarrhea account for enormous strains on society, seriously impact upon developmental potential in very poor states, and kill millions of people avoidably, international financial institutions (IFIs) might reasonably invest in supporting the foundations of sound health policies that will impact positively on long-term economic development and which will enhance the virtue of the State in the eyes of its population. Furthermore, since this subsidized, State-delivered healthcare approach is credited with having elevated Europe from grim industrial poverty to world-class regional superpower, and since unlike democracy, health is indeed a universally transferable concept, there are few sound reasons not to support such a programme. And privatizing healthcare is clearly not an option, since people with no money cannot buy monetized goods, and State legitimacy would not be a factor in such a model (Helleiner, 2001: 246-247). 
Furthermore, such investment would warrant substantial international expertise in largescale sanitation infrastructure projects, an area in which the major IFIs have significant experience, stimulating external economic investment.

At the more immediate level, vital and cheap medical healthcare could connect State institutions and public practices in a cooperative venture. Where State institutions act as vessels to funnel internationally-financed medical provisions, social expertise and area knowledge could facilitate its distribution. Such a model exists in practice already. The International Finance Facility for Immunization (IFFIm) provides for the delivery of essential immunization materials and is undertaken with local cooperation, appropriate low-level resources and combined expertise. ${ }^{3}$ Thus, IFIs and donor organizations like the World Bank, the United Nations Development Programme and UNICEF could cooperate to channel essential medical provision through national and local-level health institutions and bodies, in conjunction with extant national and international NGO expertise such as Save the Children. The State, NGOs and other local actors could transmit externallyarranged supplies (of vaccines, for example) directly to children. Indeed, the IFFIm examples demonstrate social participation and coordination in the provision of local solutions to vaccine cooling and distribution, while vaccine development itself has rendered it less sensitive to significant temperature variations, for example. These are practical, meaningful approaches to essential healthcare that enjoy local cooperation, State participation and international finance. Similar local, health-based initiatives regarding sanitation have had sustainable and positive impacts in Uganda, for example (AMREF 2008).

One critique of such an approach might be that it is small-scale. However, the effects of such delivery are much more rapid and visible than the development of political institutions and economic wealth through market liberalism; and they are easier to facilitate and spread, and are more universally acceptable. Cichon and Hagemejer point out that forms of social security provision can rapidly be established and be effective, and

\footnotetext{
${ }^{3}$ http://www.path.org/files/IFFIm_WHO.pdf. This model of funding for child immunization is provided to countries with a per capita income of under $\$ 1,000$ per annum, as long as those countries do not owe the IMF arrears.
} 
are 'direct and fast in a way that the putative benefits of "trickle down" effects of economic growth cannot match (2007: 175). Maria Ottawa refers to the glacial pace of present institution building and comments that 'it is only when the basic problem has been solved that it makes sense to talk about building institutions that will regulate the exercise of power' (2002: 1016). The 'basic problem' within a state in the immediate aftermath of elections is to create, where absent, state institutional legitimacy in order to reduce the reasons a society might have for attacking the state.

This approach can be seen as a development of Dreze and Sen's refined model of social security in the developing world. Whereas social security in the developed world has been conceptualized at relatively mild terms of 'protection from adversity and deficiency', conditions in developing countries tend to be further removed from the utility of these remits, prompting Dreze and Sen to conceptualize social protection triggers in terms of 'protection and promotion'. In this view, protection refers to stopping any decline in extant living standards. Promotion refers to 'the enhancement of general living standards...' (1989: 16). In most statebuilding spaces, the 'general living standard' is often in fact a routine struggle for daily survival, maintained through a variety of models of common social patronage, local networks, kinship relations, patron-client relations and so on (Scott 1985; Schmidt et al 1977; Roberts 2001). Instigating social conditionality as outlined above could serve both elements of Dreze and Sen's model. Local, small scale distribution practices, illustrated well by IFFIm-type practices, would protect people - especially children - from basic and preventable illnesses, whilst largerscale investment in public sanitation would furnish States with the ability to elevate life experiences beyond the most basic. Both would contribute to State legitimacy and internal stability, upon both of which the entire developmental process rests (along with the presence of traditional security measures).

The local level process could be made reasonably accountable. It could devolve the process of external medical support to local delivery means via national and international NGOs, avoiding cash transactions that may disappear within the workings of the State, whilst delivery could be monitored by a combination of local and independent observers. 
There will likely always be some degree of manipulation of resources, for reasons of greed or for reasons of essential sustenance (Wang and Rosenau, 2001; Roberts 2008a). End users including local and external medical staff could validate delivery and dissemination of vaccines, and the more efficient the dissemination, the greater additional external financial support in terms of larger lending and donations for infrastructure and other developmental goods. Ku and Diehl note the efficacy and experience of NGOs in the 'monitoring and implementation of legal instruments' or other binding agreements. They also note that NGOs have a 'range of opportunities to influence the development' of such new norms and to 'play more roles as a supplement or substitute to... international law' (2006: 167; Wang and Rosenau, 2001). They are also susceptible to internal corruption, of course.

Furthermore, such developmental programmes serve other, yet broader purposes, in bringing States into line with existing legal frameworks, rendering them meaningful rather than Utopian. By instigating such a bold social health programme, IFIs and State institutions are concurring with prestigious international laws that are sometimes ignored or considered redundant in the 'real world' and ins doing converting the rhetoric of global governance values into reality. Michael Cichon and Krzysztof Hagemejer remind us that 'social security is a fundamental societal right to which every human is entitled... laid down in Article 22 of the Universal Declaration of Human Rights; and Article 9 of the International Covenant on Economic, Social and Cultural Rights... This perspective implies that any State that has decided to become a member of the United Nations and the ILO has the general and fundamental legal obligation to put in place decent social protection for its people' (2007: 5-6).

Rather than failing in attempts to enforce accedence to international legislation, social conditionality brings IFIs and States into conformity with existing laws and undermines perceived necessity for legal transformation of the international system, a highly unlikely process unlikely to generate change in the short or medium term. This is an example of how the gap between principles in international law and their unenforceability in the international system can be closed with changing norms that are socially constructed. Ku 
and Diehl argue that the 'imbalance' between what is and what ought to be can be countered through 'actions by non-governmental organizations' along with the subsequent 'internalization of international law' (2006: 163). But advancing economic and political arguments to IFIs for policy change facilitates an effective detour around far more complex efforts to shift legal norms; and Ku and Diehl argue that, far from being naïve expectations, 'new norms [may] not upset' the international order (2006: 163). Indeed, they may enhance it in the circumstances outlined above: extra State legitimacy, enhanced human security, political stability and meaningful adherence to global governance values are all very positive outcomes. Such transformation processes have been well considered in the social constructivist literature, and Martha Finnemore and Kathryn Sikkink have presented models of when and how this process works in reality as well as in theory (1998; Moravcsik 1999). The model they have elaborated is not theory but effect-based: having observed the phenomenon of change of norms, they have demonstrated an effective working model involving the establishment of new norms via 'norms entrepreneurs'; documented the platforms used; evidenced the various tipping points and analyzed the cascade impact. Furthermore, evidence of norms change in essential child healthcare is to be found in the global immunization of infants and other aid projects (Jolly, 1995; Ingebritsen 2002). Indeed, these approaches form the very underpinning of much constructivist debate in explaining how the world changes so routinely, based on changes in the predominance of particular ideas at particular times (Cox, 1981; Elgstrom, 2000; Barnett and Finnemore, 2004).

\section{Conclusion}

One of the weakest and most important links in statebuilding is the creation of a stable domestic environment in countries emerging from wars. Emphasis - choice - is normally placed on traditional security mechanisms that reflect Realist preoccupation with the military and other disciplinarian arms of the State. This needs to stay. But it should not distract our attention from the importance of stabilizing State-society relations, and a readily disbursable means of achieving trust between the two often contrarian elements of a country is to connect them with one another through essential health provision. This perspective is quite clearly a subjective one, but so too is the present model of 
statebuilding and related assumptions of development and external funding and conditionality choices. The new State in such circumstances is precariously balanced on many competing interests and the tensions they cause. But IFIs could choose to make efficient State-based health and sanitation provision the conditions upon which initial and wider lending is based, especially since very few challenge the centrality of such issues to local State legitimacy and long term social and economic development; and especially since this model is lauded as the basis of European economic development and involves transferable and relatively easily and cheaply-created practices. The changes required are minimal, since it is ideas, beliefs and values that determine what resources go where in statebuilding; and the evidence that the markets alone cannot provide adequately in maldeveloped states is now overwhelming. This evolution of statebuilding approaches already reflects norms changes. Statebuilding 3.0 as another refinement would likely bring States into line with global governance regimes, and global governance rhetoric in line with extant international legislation, constructing a mutually-beneficial a relationship between needs in the South, power in the North, and stability for both. 


\section{References}

Alkire, S. (2004)

AMREF, (2008)

Amin, S (1977)

Barnett, M. (2006)

Barnett, $\mathrm{M}$ and

Finnemore, M (2004)

Bastian, $\mathrm{S}$ and $\mathrm{R}$

Luckham. (2003)

Bayart, J-F. (1993)

Booth, K (ed.), (2005)

Brahimi, L. (2007)

Bratton, $\mathrm{M}$ and van de

$\mathrm{N}$ van de Walle.

Bratton, M. (1989)

Brinkerhoff, DW.

Bunce, V. (2000)
'A Vital Core that must be Treated with the same Gravitas as Traditional Security Threats', Security Dialogue, 35(3): 359-60. African Medical Research Foundation, accessed $28^{\text {th }}$ April 2008 at: http://www.amref.org/index.asp?PageID=50\&PiaID=6 Imperialism and Unequal Development: Essays by Samir Amin, Sussex: The Harvester Press.

'Building a Republican Peace: Stabilizing states after war', International Security 30(2): 87-112.

Rules for the World: International Organizations in Global Politics, Ithaca: Cornell University Press.

Can Democracy be designed? The Politics of Institutional Choice in Conflict-torn Societies, London: Zed.

The State in Africa: The Politics of the Belly, London: Longman Critical Security Studies and World Politics, Boulder: Lynne Rienner.

Statebuilding in Crisis and Post-Conflict Countries, $7^{\text {th }}$ Forum on Reinventing Government, Building Trust in Government, 26-29 June 2007, Vienna, Austria.

Democratic Experiments in Africa: Regime Transitions in Comparative Perspective, Cambridge: Cambridge University Press.

'Review: Beyond the State: Civil Society and Associational Life in Africa', World Politics 41(3): 407-30.

'Rebuilding Governance in Failed States and Post-conflict Societies: Core Concepts and Cross-Cutting themes', Public Administration and Development 25: 3-14.

'Comparative Democratization: Big and Bounded

Generalizations', Comparative Political Studies 33(6/7): 703- 
34.

Burnell, $\mathrm{P}$ and V

Randall. (2005)

Carothers, T (2002)

Chandler, D (2007)

Chazan, N, P Lewis, RA Mortimer, D

Rothschild and SJ

Stedman (1999)

Cichon, $\mathrm{M}$ and $\mathrm{K}$

Hagemejer. (2007)

Clapham, C (2002)

Clapham, C (2003)

Cox, RW. (1981)

Davidson, B (1994)

Deacon, B. (2005)

Diamond, L, J Linz and SM Lipset. (1999)

Dreze, $\mathrm{J}$ and A Sen (1989)
Politics in the Developing World, Oxford: Oxford University Press.

'The End of the Transition Paradigm', Journal of Democracy 13(1): 5-21.

'The state-building dilemma: Good governance or democratic government?' In Hehir, A and Robinson, N (eds), Statebuilding: Theory and Practice, London: Routledge. Politics and Society in Contemporary Africa, Boulder: Lynne Rienner.

'Changing the development policy paradigm: Investing in a social security floor for all', International Social Security Review 60(2-3): 169-96.

'The Challenge to the State in a globalized world', Development and Change 33(5): 775-95.

'The global-local politics of state decay'. In Rotberg, RI (ed.), When States Fail: Causes and Consequences, Princeton:

Princeton University Press

'Social Forces, States and World Orders: Beyond International Relations Theory', Millennium: Journal of International Studies 10(2): 126-55.

Modern Africa: A social and political history, London: Longman.

'From “Safety Nets” Back to “Universal Social Provision”: Is the global tide turning?' Global Social Policy 5(1): 19-28.

Democracy in Developing Countries, Boulder: Lynne Rienner

Hunger and Public Action, Oxford: Oxford University Press. 
Eisenstadt, S and L 'Patron-Client Relations as a Model of Structuring Social

Roniger (1982) $\quad$ Exchange', Comparative Studies in Society and History 22(1): 42-77.

Elgstrom, O (2000) 'Norm negotiations. The Construction of New Norms regarding Gender and Development in EU Foreign Aid Policy', Journal of European Public Policy 7 (3): 457-76.

Englebert, P. (2002) State Legitimacy and Development in Africa, Boulder: Lynne Rienner.

Feit, E. (1973)

The Armed Bureaucrats, Boston: Houghton Mifflin.

Fierke, KM. (2007)

Critical Approaches to International Security, Cambridge: Polity.

Finnemore, $\mathrm{M}$ and

'International Norm Dynamics and Political Change',

Sikkink, K (1998) International Organization 52(4): 887-917.

Francois, M and I Sud 'Promoting Stability and Development in Fragile and Failed (2006) States', Development Policy Review 24(2): 141-60.

Freedman, L. (1998) 'International Security: Changing Targets', Foreign Policy, Spring: 48-64.

Grugel, J. (2002) Democratization: A Critical Introduction, London: PalgraveMacmillan

Gutteridge, WF. The Military in African Politics, London: Methuen and Co. (1969)

Hall, A and J Midgley Social Policy for Development, London: Sage (2006)

Helleiner, GK (2001) 'Markets, Politics and Globalization: Can the Global Economy be Civilized?’ Global Governance 7: 243-263.

Hooper, C. (2001) Manly States: Masculinities, International Relations and Gender Politics, New York: Columbia University Press. Ignatieff, M. (2003) Empire Lite. Nation-building in Bosnia, Kosovo and Afghanistan, New York: Vintage

ILO (2004) 'A Fair Globalization: the Role of the ILO', Report of the Director-General on the World Commission on the Social 
Dimension of Globalization, Geneva: ILO.

Ingebritsen, C (2002) 'Norms Entrepreneurs: Scandinavia's Role in World Politics', Cooperation and Conflict: Journal of the Nordic International Studies Association 37(1): 11-23.

Jackson, P. (2005) 'Chiefs, Money and Politicians: Rebuilding Local Government in postwar Sierra Leone', Public Administration and Development 25(1): 49-58.

Jolly, R (1995) Jim Grant: UNICEF Visionary, Italy: UNICEF, 2002

Kamrava, M. (1993) Politics and Society in the Third World, London: Routledge

Kannan, KP. (2007) 'Social Security in a Globalizing World', International Social Security Review 60 (2-3): 19-37.

Kilson, ML. (1963) 'Authoritarian and Single-Party Tendencies in African Politics, World Politics, January: 262-294.

Kingsbury, D. (2007) Political Development, London: Routledge.

$\mathrm{Ku}, \mathrm{C}$ and PF Diehl. $\quad$ 'Filling in the Gaps: Extrasystemic Mechanisms for addressing (2006) Imbalances between the International Legal Operating System and the Normative System’, Global Governance 12: 161-183.

Levi-Strauss (1969) The Elementary Structures of Kinship, Boston: Beacon Press

Lewis, WH. (1993) 'Peacekeeping: The Deepening Debate', Strategic Review 21(3): 26-32.

Lumumba-Kasongo, Liberal Democracy and its Critics in Africa: Political T. (ed.) (2005) Dysfunction and the Struggle for Social Progress, London: Zed Mack, A. (ed.), (2005) The Human Security Report 2005: War and Peace in the $21^{\text {st }}$ century, Oxford: Oxford University Press.

Mackinlay, J and J 'A Draft Concept of Second Generation Multinational

Chopra (1993) Operations', Thomas J Watson Institute for International Studies, Brown University.

Meredith, M. (2005) The State of Africa: A History of Fifty Years Independence, London, Free Press.

Miall, H. (2007) Emergent Conflict and Peaceful Change, London: Palgrave Macmillan. 
Migdal, JS. (1974)

Milliken, $\mathrm{J}$ and $\mathrm{K}$

Krause (2002)

Moravcsik, A (1999)

Murphy, CN. (2000)

Ottaway, M. (2002)

Parry, G. (1971)

Patrick, S and K

Brown (2007)

Phan Huy Le (1993)

Randall, V and R

Theobald (1985)

Roberts, D. (2001)

Roberts, D. (2008a)

Roberts, D. (2008b)

Rodney, W. (1973)

Rothstein, RL. (1992)
'Towards a New Theory of Change Amongst Individuals in the Process of Modernization', World Politics: A Quarterly Journal c International Relations XXVI(2): 189-206.

'State failure, State Collapse, and State reconstruction:

Concepts, Lessons and Strategies', Development and Change 33(5): 753-74.

'A New Statecraft? Supranational Entrepreneurs and International Cooperation', International Organization 53: 267306.

'Global governance: poorly done and poorly understood', International Affairs 4: 789-803.

'Rebuilding State institutions in Collapsed States', Development and Change 33(5): 1001-23.

Political Elites, London: Allen and Unwin.

Greater than the Sum of its Parts? Assessing 'Whole of

Government' Approaches to Fragile States, New York:

International Peace Academy.

The Traditional Village in Viet Nam, Hanoi: The Gioi Press.

Political Change and Underdevelopment: A Critical

Introduction to Third World Politics, Basingstoke: Macmillan.

Political Transition in Cambodia, 1991-1999: Power, Elitism

and Democracy, London: CurzonRoutledge.

'Hybrid Polities and Indigenous Pluralities: Advanced Lessons

in Statebuilding', Journal of Intervention and Statebuilding 2(1): 379-402.

Human Insecurity: Global Structures of Violence, London: Zed. How Europe Underdeveloped Africa, London and Tanzanian Publishing House, Dar-Es-Salaam: Bogle l’Ouverture.

'Weak Democracy and the Prospect for Peace and Prosperity in the Third World'. In Sheryl J. Brown and Kimber M. Schraub (eds) Resolving Third World Conflicts: Challenges for a New 
Era. Washington, DC: US Institute of Peace.

Rustow, DA. (1970) 'Transitions to Democracy: Toward a Dynamic Model’, Comparative Politics 2(3): 337-63.

SarDesai, DR. (1992) V Vietnam: The Struggle for National Identity, Boulder, Colorado: Westview Press, 1992.

Schmidt, SW, JC Friends, Followers and Factions: A Reader in Political

Scott, C Lande \& L Clientelism, Berkeley: University of California Press

Guasti (1977)

Scott, JC. (1985)

Weapons of the Weak: Everyday Forms of Peasant Resistance, New Haven: Yale

Stoett, P. (1999)

Human and Global Security: An Exploration of Terms, Toronto: University of Toronto Press.

Taback, N and R. $\quad$ 'The science of human security', Medicine, Conflict and Coupland (2007) Survival 23(1): 3 - 9.

Tambiah, SJ. (1977) 'The Galactic Polity: the Structure of Traditional Kingdoms in Southeast Asia'. In Freed, S (Ed.), Anthropology and the Climate of Opinion, Annals of the New York Academy of Sciences, 293.

Thomson, A. (2000) An Introduction to African Politics, London: Routledge. Tickner, JA. (1992) Gender in International Relations: Feminist Perspectives in Achieving Global Security, New York: Columbia University Press.

United Nations $\quad$ United Nations Human Development Report 2005:

Development International cooperation at a crossroads - aid, trade and Programme (2005) Security in an unequal world, New York: UNDP.

Vickery, M. (1984)Ｃambodia 1975-1982, Boston: Southend Press.

Von Einsedel (2005) 'Policy responses to state failure'. In Chesterman, S, Ignatieff, $\mathrm{M}$ and Thakur, R (Eds.), Making States Work: State Failure and the Crisis of Governance, Tokyo: United Nations University Press.

Walker, RBJ (ed), $\quad$ Culture, Ideology and World Order, London: Westview. 
Wang, Hongying and 'Transparency International and Corruption as an Issue of James N Rosenau Global Governance’, Global Governance 7: 25-49. (2001)

Wendt, A. (1999)

Social Theory of International Politics, Cambridge: Cambridge University Press.

Wolf, E. (1966)

'Kinship, Friendship, and Patron-Client Relationships in Complex Societies'. In Banton, M (Ed), The Social Anthropology of Complex Societies, London: Tavistock.

World Health World Health Report 2005: Make Every Mother and Child Organisation (2005) Count, Geneva: WHO

World Health The World Health Report 2007 - A Safer Future: Global Public

Organisation (2007) Health Security In The 21st Century, Geneva: WHO.

Yeates, N. (2001) Globalization and Social Policy, London: Sage

Zakaria, F. (1997) ‘The Rise of Illiberal Democracy', Foreign Affairs 76(6): 22-43 